\title{
Biermer Disease: Initial Presentation and Follow-Up of 66 Patients in Internal Medicine Department in Senegal
}

\author{
Seynabou Fall'1, Nafissatou Diagne², Oulimata-Dior Diop", Boundia Djiba², \\ Fatou-Samba-Diago Ndiaye ${ }^{1}$, Abdoulaye Pouye ${ }^{2}$ \\ ${ }^{1}$ Clinical Haematology Unit of Internal Medicine Department, Aristide Le Dantec University Teaching Hospital, Dakar, Senegal \\ ${ }^{2}$ Internal Medicine Department, Aristide Le Dantec University Teaching Hospital, Dakar, Senegal \\ Email: seyna.fall@gmail.com
}

How to cite this paper: Fall, S., Diagne, N., Diop, O.-D., Djiba, B., Ndiaye, F.-S.-D. and Pouye, A. (2016) Biermer Disease: Initial Presentation and Follow-Up of 66 Patients in Internal Medicine Department in Senegal. International Journal of Clinical Medicine, 7, 585-591.

\section{http://dx.doi.org/10.4236/ijcm.2016.79064}

Received: July 20, 2016

Accepted: August 29, 2016

Published: September 5, 2016

Copyright $\odot 2016$ by authors and Scientific Research Publishing Inc. This work is licensed under the Creative Commons Attribution International License (CC BY 4.0).

http://creativecommons.org/licenses/by/4.0/

\begin{abstract}
Pernicious anemia in black people, is little known. Through this study we assess its diagnostic and evolutive aspects, and compare vitamin therapy B12 intramuscular and oral. Sixty six Biermer disease patients followed (January 2000-June 2014) at Internal Medicine Department of Aristide Le Dantec University Teaching Hospital (Senegal) are included. They were 26 men and 46 women (gender ratio: 0.65), who had a mean age of 47.84 years \pm 15.25 years. Patients consulted for anemia ( 65 cases), acquired melanodermia (36 cases), gastrointestinal symptoms (30 cases), peripheral neuropathy (27 cases), venous thrombosis ( 2 cases), acute depression (1 case). Macrocytosis was observed in 52 cases. The mean hemoglobin in the vitamin B12 intramuscular group (52 patients) or oral group (14 patients) was the inclusion: 6.55 $\mathrm{g} / \mathrm{dl} \pm 3.12 \mathrm{~g} / \mathrm{dl}$ vs $6.52 \mathrm{~g} / \mathrm{dl} \pm 2.18 \mathrm{~g} / \mathrm{dl}(\mathrm{p}=0.04)$; and at day 8 treatment: $8.69 \mathrm{~g} / \mathrm{dl} \pm$ $2.49 \mathrm{~g} / \mathrm{dl}$ vs $8.85 \mathrm{~g} / \mathrm{dl} \pm 1.9 \mathrm{~g} / \mathrm{dl}(\mathrm{p}=0.43)$. Neurological and vascular presentations are unusual in contrast to macrocytic anemia. Oral administration of vitamin B12, simple and effective should be recommended in country with limited resources.
\end{abstract}

\section{Keywords}

Pernicious Anemia, Intramuscular Vitamin B12, Oral Vitamin B12, Senegal

\section{Introduction}

Biermer disease or pernicious anemia is a chronic auto-immune disease responsible for a chronic gastritis and a vitamin B12 deficiency, reversible under vitamin B12 therapy which oral administration is validated [1]. It is considered rare in black people and re- 
lated literature in sub-Saharan Africa is limited to few case reports [2]-[5]. To our knowledge no publications about practice of oral vitamin therapy B12, is available in sub-Saharan Africa. With this series we propose to describe diagnostic and progression aspects, and to compare outcome on vitamin therapy B12, intramuscular and oral.

\section{Patients and Methods}

It is a retrospective, descriptive study with analytical outlook conducted upon comprehensive enrollment of medical files of Biermer disease patients followed from $1^{\text {st }}$ January 2000 to $30^{\text {th }}$ June 2014. The study held at Internal Medicine Department of superior referral hospital of Aristide Le Dantec University Teaching Hospital (Senegal) which has consultation, hospitalization and research activities. Our study included 66 files of Biermer disease, onto an annual average of 685 inpatients and 14,871 outpatients at Internal Medicine Department.

The diagnosis of Biermer disease was made in the presence of positive anti-intrinsic factor or anti-parietal cells antibodies, associated or not with vitamin B12 deficiency and atrophic gastritis [1]. Epidemiological, clinical and paraclinical data were analyzed. Bone marrow aspiration and analysis provided precision on the existence of megaloblastosis. Vitamin B12 deficiency was defined by measurements below normal values between 187 and $883 \mathrm{pg} / \mathrm{ml}$.

Positive anti-intrinsic factor and anti-parietal cells antibodies were defined by measurements higher than 1.53 and $40 \mathrm{AU} / \mathrm{ml}$ respectively. Upper gastro-intestinal-tract (GIT) endoscopy with systematic antrum and fundusbiopsies and histology revealed gastric atrophy, metaplasia and helicobacter pylori (HP).

Cyanocobalamine is administered intramuscularly $(1000 \mu \mathrm{g}$ once a day for the $1 \mathrm{st}$ week, then once a week for a month and once a month for life) or orally (2000 $\mu \mathrm{g}$ per day for 10 days, followed by the same dose once a week for 4 weeks and then once a month for life). Indications for oral administration were: Ongoing anticoagulation, thrombocytopenia below $50,000 / \mathrm{mm}^{3}$ and difficult access to intramuscular injections. The median follow-up of patients treated with vitamin B12 (oral or intramuscular) was 1135.72, days [8 - 4886 days].

Statistic tests (medium, standard deviation, Student test) were done using Statistical Package for Social Sciences 20 software.

\section{Results}

The files of 40 women and 26 men (gender ratio: 0.65 ), with mean age of 47.84 years \pm 15.25 were included.

Comorbidities were metrorrhagia ( 2 cases), hemorrhagic cystitis ( 1 case) and partial gastrectomy for a benign tumour ( 1 case), vitiligo (5 cases), type 2 diabetes mellitus, Hashimoto thyroiditis ( 2 cases) and multiple auto immune disease syndrome ( 2 cases).

In 28 medical files blood group was specified and it was $\mathrm{O}$ (12 cases), A (7 cases), B (7 cases) and $\mathrm{AB}$ ( 2 cases)

Mean diagnostic time was 16 months (6 - 48 months). Presenting symptoms (Table 1) were anemia signs (65 cases), palmo-plantar acquired diffuse melanodermia (36 
Table 1. Clinical and paraclinical characteristics of the patients of our study.

\begin{tabular}{|c|c|c|}
\hline Clinical signs on diagnosis & $\mathrm{n} / \mathrm{N}=66$ & (\%) \\
\hline \multicolumn{3}{|l|}{ Anemia manifestations } \\
\hline Anemic syndrome & 40 & $(60.6)$ \\
\hline Hemolytic anemia & 13 & $(19.7)$ \\
\hline Anemic heart disease & 7 & $(10.6)$ \\
\hline Isolated conjunctiva pallor & 5 & $(7.6)$ \\
\hline \multicolumn{3}{|l|}{ GIT manifestations } \\
\hline Epigastric pain & 30 & $(45.5)$ \\
\hline glossitis & 21 & $(31.8)$ \\
\hline diarrhea & 6 & (9) \\
\hline constipation & 4 & (6) \\
\hline dysphagia & 3 & $(4.5)$ \\
\hline \multicolumn{3}{|l|}{ Dermatologic manifestations } \\
\hline melanodermia & 36 & $(54.5)$ \\
\hline \multicolumn{3}{|l|}{ Neuropsychiatric manifestations } \\
\hline polyneuropathy & 27 & $(40.9)$ \\
\hline posterior cord syndrom & 1 & $(1.5)$ \\
\hline Acute depression & 1 & $(1.5)$ \\
\hline \multicolumn{3}{|l|}{ Venous manifestations } \\
\hline Saphenous and femoral thrombophlebitis & 1 & $(1.5)$ \\
\hline Portal vein thrombosis incidentally discovered & 1 & $(1.5)$ \\
\hline$\underline{\text { Paraclinical signs }}$ & $\mathrm{n} / \mathrm{N}$ & (\%) \\
\hline Anemia & $65 / 66$ & $(98.5)$ \\
\hline Thrombocytoenia & $33 / 66$ & $(50)$ \\
\hline Leukocytopenia & $29 / 66$ & $(43.9)$ \\
\hline Pancytopenia & $25 / 66$ & $(37.9)$ \\
\hline Bicytopenia & $18 / 66$ & $(27.3)$ \\
\hline Thrombocytosis & $2 / 66$ & (3) \\
\hline Hyperleukocytosis & $1 / 66$ & $(1.5)$ \\
\hline Vitamin B12 deficiency & $59 / 66$ & $(89.39)$ \\
\hline Central megaloblastosis & $37 / 47$ & $(88.1)$ \\
\hline Positive anti-intrinsic factor antibodies & $50 / 51$ & $(98.03)$ \\
\hline Positive anti-parietal cells antibodies & $25 / 36$ & $(69.44)$ \\
\hline Atrophic gastritis & $34 / 37$ & $(91.89)$ \\
\hline Antrum and pyloric metaplasia & $10 / 37$ & $(27.02)$ \\
\hline Helicobacter pylori & $2 / 37$ & $(5.4)$ \\
\hline
\end{tabular}

$\mathrm{N}$ : Total number of patients who did the test; $\mathrm{n}$ : Number of patients with abnormalities; \%: Percentage.

cases), GIT signs including Hunter glossitis (21), polyneuropathy (27 cases) which one posterior cord syndrom, acute transient depression (1 case) and deep venous thrombosis $(2$ cases). The discovery of the disease was incidental in one patient who only had macrocytosis with no anemia (1).

Blood count (BC) (Table 1 \& Table 2) revealed anemia (65 cases), macrocytosis (52 
Table 2. Blood Count and reticulocyte count: At the beginning of the study and progression according to the administration route of vitamin B12.

\begin{tabular}{|c|c|c|c|c|c|}
\hline Parameters & Beginning of the study & \multicolumn{2}{|c|}{ Mean } & \multicolumn{2}{|c|}{ SD Extreme } \\
\hline $\mathrm{D} 0: \mathrm{Hb}(\mathrm{g} / \mathrm{dl})$ & 6.52 & \multicolumn{2}{|c|}{2.93} & \multicolumn{2}{|l|}{$[1.3-15.2]$} \\
\hline $\operatorname{MCV}(\mathrm{fl})$ & 107.04 & \multicolumn{2}{|c|}{11.36} & \multicolumn{2}{|l|}{$[81-131]$} \\
\hline $\mathrm{MCTH}$ & 34.4 & \multicolumn{2}{|c|}{5.04} & \multicolumn{2}{|l|}{$[22-42.06]$} \\
\hline $\operatorname{PLT}(\mathrm{G} / \mathrm{L})$ & 148.31 & \multicolumn{2}{|c|}{487.44} & \multicolumn{2}{|l|}{$[170-488]$} \\
\hline WBC $(\mathrm{G} / \mathrm{L})$ & 4.39 & \multicolumn{2}{|c|}{2.17} & \multicolumn{2}{|c|}{$[1.5-15.10]$} \\
\hline Ret. count (G/L) & 30.89 & \multicolumn{2}{|c|}{29.24} & \multicolumn{2}{|l|}{$[2-98]$} \\
\hline \multicolumn{5}{|c|}{ According to the route of administration of vitamin $\mathrm{B} 12$} & $\mathrm{p} ¥$ \\
\hline & Intramuscular $(\mathrm{N}=52)$ & (n) Mean SD & Oral $(\mathrm{N}=14)$ & (n) Mean SD & \\
\hline $\mathrm{D} 0: \mathrm{Hb}(\mathrm{g} / \mathrm{dl})$ & (52) 6.55 & 3.12 & (14) 6.52 & 2.18 & 0.43 \\
\hline $\operatorname{MCV}(\mathrm{fl})$ & 106.06 & 11.76 & 110.66 & 9.21 & 0.09 \\
\hline Ret. count (G/L) & 55.26 & 29.78 & 49.29 & 28.74 & 0.37 \\
\hline D8: $\mathrm{Hb}$ (g/dl) & (52) 8.69 & 2.49 & (14) 8.85 & 1.9 & 0.83 \\
\hline $\operatorname{MCV}(\mathrm{fl})$ & 100.03 & 10.72 & 99.53 & 8.51 & 0.89 \\
\hline Ret. count $(\mathrm{G} / \mathrm{L})$ & 104.65 & 102.78 & 145.52 & 87.39 & 0.27 \\
\hline M1: Hb (g/dl) & (41) 10.83 & 2.23 & (12) 11.81 & 1.16 & 0.16 \\
\hline $\operatorname{MCV}(\mathrm{fl})$ & 94.0 & 13.34 & 90.91 & 6.81 & 0.18 \\
\hline Ret. count(G/L) & 149.58 & 130.70 & 212.21 & 79.71 & 0.22 \\
\hline M6: Hb (g/dl) & (23) 12.71 & 1.89 & (12) 13.33 & 1.02 & 0.96 \\
\hline $\operatorname{MCV}(\mathrm{fl})$ & 86.02 & 8.60 & 86.14 & 8.28 & 0.97 \\
\hline Ret count (G/L) & 213.76 & 102.32 & 297.00 & 54.76 & 0.04 \\
\hline
\end{tabular}

$\mathrm{N}$ : total number of patients treated, n: number of patients explored; Hb: hemoglobin; MCV: Mean Corpuscular Volume; Ret Count: reticulocyte count; SD: Standard deviation; Mean: Mean value; D0: Day 0 on admission; D8: Day 8; M1: $1^{\text {st }}$ month; M6: $6^{\text {th }}$ month; $p:$ Student test.

cases) and hypochromia (4 cases). One patient had isolated macrocytosis at $115 \mathrm{fl}$ with hemoglobin of $15.2 \mathrm{~g} / \mathrm{dl}$. The mean hemoglobin was $6.52 \mathrm{~g} / \mathrm{dl} \pm 2.93 \mathrm{~g} / \mathrm{dl}$ was below 6 $\mathrm{g} / \mathrm{dl}$ in $47.7 \%$ of patients. BC (Table 1) also revealed thrombocytopenia (39 cases) out of which 7 were below $50 \mathrm{G} / \mathrm{L}$ without bleeding, leukocytopenia (28 cases), thrombocytosis at $460 \mathrm{G} / \mathrm{L}$ reactive to iron deficiency, and thrombocytosis at $488 \mathrm{G} / \mathrm{L}$ associated with leukocytosis at $15.1 \mathrm{G} / \mathrm{L}$ in the context of pyelonephritis. There were cytopenias in form of pancytopenia (25 cases) and bicytopenia (18 cases). Reticulocyte count was low in all patients (Table 2). Traces of hemolysis were noted in 18 patients who had mean $\mathrm{LDH}$ at 522IU/1 [451 - $612 \mathrm{UI} / \mathrm{l}]$ and direct serum bilirubin at $21 \mathrm{mg} / 1$ [13 - $32 \mathrm{mg} / \mathrm{l}]$.

In addition to $\mathrm{BC}$ abnormalities, we found megaloblastosis (88.7\%), positive anti intrinsic factor (98.03\%) and anti parietal cells antibodies (69.40\%), atrophic gastritis (91.89\%) and HP infection (5.4\%) (Table 1).

Overall evolution after intramuscular (52 cases) or oral (14 cases) vitamin therapy $\mathrm{B} 12$ is favorable. On day eighth, is observed a mean reticulocytosis crisis of $119.63 \mathrm{G} / \mathrm{L}$ $\pm 97.94 \mathrm{G} / \mathrm{L}$ [ 36 to $466.46 \mathrm{G} / \mathrm{L}$ ]. Hemoglobin levels is rising during vitamin B12 administration (Figure 1). Hemoglobin levels increased after 6 months in $83.9 \%$ of patients 


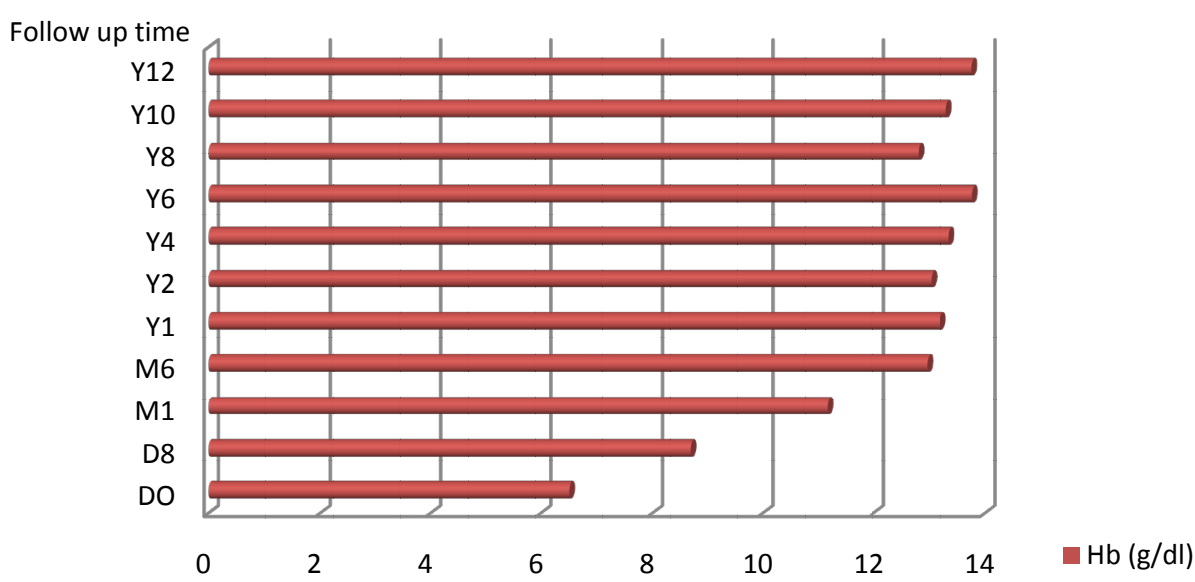

D0 : day on admission ;D8: day eight; M1 : $1^{\text {st }}$ month ; M6: $6^{\text {th }}$; month; Y1: $1^{\text {st }}$ year; y2: $2^{\text {nd }}$ year $;$ Y $4: 4^{\text {th }}$ year; Y6: $6^{\text {th }}$ year $;$ Y8: $8^{\text {th }}$ year; Y10: $10 t^{\text {th }}$ year $; Y 12: 12^{\text {th }}$ year $\mathrm{Hb}$ : mean of hemoglobin ;

Figure 1. Evolution of the average rate of hemoglobin.

and after 1 year the improvement was at $91.7 \%$ of patients.

In analytical study the mean hemoglobin level on vitamin B12 supplements in the intramuscular group versus oral, was on day eight $8.69 \pm 2.5 \mathrm{~g} / \mathrm{dl} \mathrm{Vs} 8.85 \pm 1.9 \mathrm{~g} / \mathrm{dl}$ (p = $0.43)$ and after 1 month it was $10.83 \pm 2.2 \mathrm{~g} / \mathrm{dl} \mathrm{Vs} 11.81 \pm 1.1 \mathrm{~g} / \mathrm{dl}(\mathrm{p}=0.16)$ (Table 2). In oral group the reticulocyte count which was at $49.29 \mathrm{G} / \mathrm{L}$ initially rose to $297 \mathrm{G} /$ Lafter 6 months (Table 2).

\section{Discussion}

The available literature on Biermer disease in sub-Saharan Africa is made of limited series.

In 2003, Segbenaet al [2] reported 4 observations and in 2013, Diopet al [3] collected 28 cases over 6 years. To our knowledge, our study is the largest series carried out in Senegal (66 cases) and is the $1^{\text {st }}$ describing oral vitamin B12 therapy.

In our study as well as in other african publications [2]-[5], Biermer disease is common in women in their fifties. Predominant signs on presentation in our study were anemia signs, which also were almost present in de Segbenaet al [2] and Ndiaye et al. [4] with respective prevalences of $100 \%$ and $80 \%$.

In our study, anemia signs are predominantly made of anemic syndromefar ahead of hemolytic anemia and anemic heart disease. Heart failure as described in our patients is a chronic complication of cardiovascular manifestations common to all vitamin B12 deficiencies as described in almost $50 \%$ of cases by Nafil et al. [6].

Acquired melanodermia, second presenting sign in our study is also frequently reported in African publications [3] [4]. It is a diffuse homogenous melanodermia with buccal and palmo-plantar predominance secondary to disturbed tyrosine synthesis, this being a melanin precursor [7].

The third diagnostic condition in our study was GIT signs with atypical epigastric 
pain, followed by Hunter glossitis. This one is more specific of Biermer disease and was noted in $78.57 \%$ of patients in Diop et al. series [3].

The least observed manifestation in our patients was deep venous thrombosis. As a comparison Zulfiquar et al. [8] and Diop et al. [3] respectively reported 10 and 2 observations.

Beside thrombosis, acute depression and combined sclerosis of the bone marrow are rare in our study (1 case) like in the literature [4] [8] [9].

Main BC abnormalities were macrocytic anemia followed by thrombocytopenia and neutropenia both in our patients and in Song and al series [10] who reported 65\% of thrombocytopenia and $45.5 \%$ of leucopenia. However some authors [11] didn't note any difference in the prevalence of leukocytopenia and thrombocytopenia. These cytopenias are more combined into pancytopenia orbicytopenia [3] [4] [8]. Early diagnosis at the macrocytosis stage before cytopenia is rare [5], we only hadone observation. Beside the frequent macrocytosis, normocytosis and hypochromia are not exceptional [3] [8]. They are due to additional factors like iron deficiency in bleeding of our patients for example or other comorbidities like association with beta thalassemia and Plummer Vinson [3].

Characteristic bone marrow aspirate findings in our study were the high frequency of megaloblastosis, coinciding with results of de Segbena et al. [2] (100\%) and Wun Chan et al. [9] (95\%).

Positive anti-intrinsic factor antibody which is more specific of the disease [3] [9], was almost constantly present in our study.

Prevalence of atrophic gastritis was high unlike HP surinfection which was rare. Similar findings in this regard were also obtained by Wun Chun et al. [9] who published cases of HPsurinfection par HP in 109 Biermer disease patients who underwend upper GIT endoscopy with biopsies.

On therapeutic aspect, hematologic abnormalities are reversible with vitamin B12 treatment, more frequently administered intramuscularly in our study and in the literature [1] [4]. Song et al. [10] noted that $94.3 \%$ of anemia regressed after 3 months treatment with vitamin B12.

Oral route of administration is effective and is indicated in case of severe thrombocytopenia or anticoagulation treatment [1]. In addition therapeutic compliance is better obtained with oral administration in patients with difficult access to health care. In analytical study we noted that oral vitamin B12 allowed cytopenia regression by day eight and reticulocytosis was statistically significant after 6 months. The absence of statistical significance of some of our tests was a bias due to the limited number our series enrolled.

\section{Conclusion}

Macrocytic anemia and acquired melanodermia are frequently revealing sign of Biermer disease, in contrast to neuropyschiatric and vascular manifestations. Oral route of vitamin B12 administration, simple and equally effective should be strongly promoted 
in sub-Saharan Africa regions with limited resources.

\section{References}

[1] Andres, E. and Serraj, K. (2012) Optimal Management of Pernicious Anemia. Journal of Blood Medicine, 3, 97-103. http://dx.doi.org/10.2147/JBM.S25620

[2] Segbena, A.Y., Ambofo-Planche, Y., Gbadoe, A.D., et al. (2003) Biermer's Anemia in West Africa: Report of Four Cases. Médecine Tropicale, 63, 593-596.

[3] DiopMadoky, M., Berthe, A., Toure, P.S., et al. (2013) Peculiarities of Biermer Disease in a senegalese Internal Medicine Department: A 6 Year Prospective Study. Journal of Blood Disorders \& Transfusion, 5, 3 p.

[4] Ndiaye, F.S.D., Fall, S., Sarr, A., Laraki, S.D., Ka, M.M. and Diop, T.M. (2009) Update of Pernicious Anemia: A Retrospective Study of 26 Senegalese Cases. Hématologie, 15, 473477.

[5] Diop, S., Ka, M.M., Mbengue, M., Dangou, J.M., Pouye, A., Thiam, D., et al. (1999) Biermer Disease without Anemia: A Report of 2 Cases Manifested by Glossitis with Macrocytosis. Dakar Médical, 44, 134-136.

[6] Nafil, H., Tazi, I., Sifessalam, M., Bouchtia, M. and Mahmal, L. (2013) Anaemia Due to Vitamin B12 Deficiency in the Region of Marrakech (Morocco). Revue d' Épidémiologie et de Santé Publique, 61, 78-81. http://dx.doi.org/10.1016/j.respe.2012.07.003

[7] Ben Kacem Ernez, S., Ach, K., Maaroufi, A., Zaouali, M., Chaieb, M.C., et al. (2004) Hyperpigmentation in Pernicious Anaemia. La Revue de Médecine Interne, 25, 475-476.

[8] Zulfiqar, A.A., Pennaforte, J.L. and Andres, E. (2014) Clinical, Haematological and Biological Characteristics of 158 Patients Followed for Biermer Disease. La Revue de Médecine Interne, $35,1 \mathrm{p}$.

[9] Wun Chan, J.C., Yu Liu, H.S., Sang Kho, B.C., et al. (2006) Pernicious Anemia in Chinese: A Study of 181 Patients in a Hong Kong Hospital. Medicine, 85, 129-138. http://dx.doi.org/10.1097/01.md.0000224710.47263.70

[10] Song, I.C., Lee, H.J., Kim, H.J., et al. (2013) A Multicenter Retrospective Analysis of the Clinical Features of Pernicious Anemia in a Korean Population. Journal of Korean Medical Science, 28, 200-204. http://dx.doi.org/10.3346/jkms.2013.28.2.200

[11] Andres, E., Mecili, M. and Ciobanu, E. (2010) Internist Presentations of Biermer Disease: Retrospective Study about of 80 Patients. La Revue de Médecine Interne, 31, 1 p. 
Submit or recommend next manuscript to SCIRP and we will provide best service for you:

Accepting pre-submission inquiries through Email, Facebook, LinkedIn, Twitter, etc. A wide selection of journals (inclusive of 9 subjects, more than 200 journals)

Providing 24-hour high-quality service

User-friendly online submission system

Fair and swift peer-review system

Efficient typesetting and proofreading procedure

Display of the result of downloads and visits, as well as the number of cited articles

Maximum dissemination of your research work

Submit your manuscript at: http://papersubmission.scirp.org/ 